\title{
Localisation of intrahepatic interleukin 6 in patients with acute and chronic liver disease
}

\author{
S Kakumu, A Fukatsu, T Shinagawa, S Kurokawa, A Kusakabe
}

\begin{abstract}
Aim: To evaluate the role of local interleukin 6 (IL-6) in the pathogenesis of acute and chronic liver disease.

Methods: The cellular site of $\mathrm{IL}-6$ in cryostat sections of liver from 31 patients with liver disease was examined using indirect immunofluorescence with a monoclonal antibody.

Results: IL-6 staining in sinusoidal endothelial cells was very noticeable and diffusely distributed in the lobules of specimens of acute viral hepatitis. IL-6 expression in endothelial cells, particularly in necrotic areas of hepatocytes, was increased and was accompanied by enhanced expression in Kupfier cells. In contrast, IL-6 staining in infiltrating mononuclear cells was prominent in portal tracts, and the numbers of cytokine positive cells were greater in specimens of chronic active hepatitis compared with chronic persistent hepatitis. In non-specific reactive hepatitis intrahepatic expression of IL-6 was minimal, while in alcoholic liver fibrosis the cytokine distribution in the lobules was similar to that of acute viral hepatitis.

Conclusion: These results indicate that locally produced IL-6 contributes to the inflammatory process and immunological response in acute and chronic liver disease.
\end{abstract}

Interleukin-6 (IL6), also known as B cell stimulatory factor 2 (BSF-2), induces the final maturation of $\mathbf{B}$ cells to antibody producing infected tissue, ${ }^{2-4}$ IL- 6 may exert its major disease of various aetiologies were studied (table). They had been diagnosed on the basis of appropriate serological, virological, biochemical, and histological criteria. ${ }^{12}$ Five patients with acute viral hepatitis underwent liver biopsy two to three weeks after onset of their illness. Three were biopsied when their serum aminotransferase activities had returned to normal, and the histological findings indicated non-specific reactive hepatitis.

Serum HBsAg, anti-HBs, anti-HBc, $\mathrm{HBeAg}$ and anti-HBe were assayed by commercial radioimmunoassay kits (Abbot Laboratories, North Chicago, Illinois, USA). Hepatitis $B$ infection was diagnosed if antibodies to $\mathrm{HBsAg}$ were positive. Non-A, non$B$ hepatitis (type C) was diagnosed by the detection of serum HCV RNA using the polymerase chain reaction ${ }^{13}$; all patients diagnosed as having non- $\mathrm{A}$, non-B hepatitis were positive for HCV RNA except for one with chronic persistent hepatitis.

Liver biopsy samples obtained from all patients were divided into two. One part was fixed in $10 \%$ formalin for routine histological examination. The other part was immediately frozen in liquid nitrogen with OLT compound (Miles Inc Elkhart, England) and used for immunofluorescence microscopy. ${ }^{14}$ Sections of frozen tissue $2-3 \mu \mathrm{m}$ thick were cut by cryostat and fixed in acetone for 15 minutes at room temperature. The sections were incubated with normal goat serum diluted 1 in 40. After washing in phosphate buffered saline (PBS), pH 7.4, sections were incubated with properly diluted mouse monoclonal antibody against human recombinant IL- 6 for $30 \mathrm{~min}$ utes at room temperature. After washing in PBS, they were incubated with fluorescent isothiocyanate (FITC)-labelled second antibody. Non-relevant antibodies of the same class and normal rabbit serum were used for the control study. The slides were then covered with medium containing phenylene diamine and observed with an Olympus $\mathrm{BH}-2$ epifluorescence microscope equipped with proper filters (Tokyo, Japan).

The characterisation and specificity of a monoclonal antibody of IgM class to human recombinant IL-6 has been described previously. ${ }^{15}$ As a second antibody an IgG fraction of goat anti-mouse $\operatorname{IgM}$ antiserum was used, which had been preabsorbed with normal human serum not to cross-react with the antibodies to human liver tissues. The binding of anti-IL-6 monoclonal antibody to the liver section was completely blocked by preincubation with recombinant IL-6. cells. ${ }^{1}$ Recent studies have indicated that IL- 6 has many biological properties including affecting the immune and inflammatory responses. $^{2-4}$ IL- 6 production can be induced by a wide variety of agents in many different cells such as monocytes, $T$ cells, $B$ cells, fibroblasts, endothelial cells, epithelial cells, etc.

As IL- 6 is mainly released from injured or influence in local tissue like other cytokines, as suggested in certain inflammatory diseases..$^{5-10}$ We therefore decided to evaluate the localisation of IL-6 in liver tissue to understand precisely whether it has a role in acute and chronic hepatitis. ${ }^{11}$

Methods

Thirty one patients with acute or chronic liver

Third Department of
Internal Medicine,
Nagoya University
School of Medicine,
Nagoya, Japan
S Kakumu
A Fukatsu
T Shinagawa
Department of
Internal Medicine,
Nagoya First Red
Cross Hospital,
Nagoya, Japan
S Kurokawa
A Kusakabe
Correspondence to:
Dr Shinichi Kakumu, Third
Department of Internal
Medicine, Nagoya
University School of
Medicine, 65 Tsuruma-cho,
Showa-ku, Nagoya 466,
Japan
Accepted for publication
30 October 1991


Distribution and prevalence of IL-6 positive cells in liver tissues of 31 patients with various liver diseases

\begin{tabular}{|c|c|c|c|c|c|c|c|c|c|}
\hline \multirow[b]{2}{*}{ Diagnosis } & \multirow[b]{2}{*}{ No } & \multirow[b]{2}{*}{ Age (years) } & \multirow[b]{2}{*}{$\operatorname{Sex}(F / M)$} & \multicolumn{3}{|c|}{$\begin{array}{l}\text { Distribution of } I L-6^{+} \text {endothelial } \\
\text { cells }\end{array}$} & \multicolumn{3}{|c|}{$\begin{array}{l}\text { Prevalence of IL-6 } \\
\text { infiltrating mononuclear cells }\end{array}$} \\
\hline & & & & Spotty & Focal & Diffuse & + & ++ & +++ \\
\hline Non-specific reactive hepatitis & 3 & $36-52$ & $1 / 2$ & 3 & 0 & 0 & 3 & 0 & 0 \\
\hline $\begin{array}{l}\text { Acute hepatitis } \\
\text { type A } \\
\text { type } B \\
\text { non-A, non-B }\end{array}$ & $\begin{array}{l}2 \\
2 \\
3\end{array}$ & $\begin{array}{l}23-30 \\
21-32 \\
22-45\end{array}$ & $\begin{array}{l}0 / 2 \\
1 / 1 \\
1 / 2\end{array}$ & $\begin{array}{l}0 \\
0 \\
0\end{array}$ & $\begin{array}{l}0 \\
0 \\
0\end{array}$ & $\begin{array}{l}2 \\
2 \\
3\end{array}$ & $\begin{array}{l}0 \\
1 \\
1\end{array}$ & $\begin{array}{l}2 \\
1 \\
2\end{array}$ & $\begin{array}{l}0 \\
0 \\
0\end{array}$ \\
\hline $\begin{array}{l}\text { Chronic persistent hepatitis } \\
\text { type B } \\
\text { non-A, non-B }\end{array}$ & $\begin{array}{l}5 \\
2\end{array}$ & $\begin{array}{l}20-55 \\
43-48\end{array}$ & $\begin{array}{l}2 / 3 \\
1 / 1\end{array}$ & $\begin{array}{l}\mathbf{0} \\
\mathbf{0}\end{array}$ & $\begin{array}{l}4 \\
2\end{array}$ & $\begin{array}{l}1 \\
0\end{array}$ & $\begin{array}{l}4 \\
2\end{array}$ & $\begin{array}{l}1 \\
0\end{array}$ & $\begin{array}{l}0 \\
0\end{array}$ \\
\hline $\begin{array}{l}\text { Chronic active hepatitis } \\
\text { type } B \\
\text { non-A, non-B } \\
\text { Alcoholic liver fibrosis }\end{array}$ & $\begin{array}{l}6 \\
5 \\
3\end{array}$ & $\begin{array}{l}19-62 \\
28-59 \\
49-58\end{array}$ & $\begin{array}{l}2 / 4 \\
3 / 2 \\
0 / 3\end{array}$ & $\begin{array}{l}0 \\
0 \\
0\end{array}$ & $\begin{array}{l}3 \\
3 \\
0\end{array}$ & $\begin{array}{l}3 \\
2 \\
3\end{array}$ & $\begin{array}{l}2 \\
2 \\
2\end{array}$ & $\begin{array}{l}3 \\
2 \\
1\end{array}$ & $\begin{array}{l}1 \\
1 \\
0\end{array}$ \\
\hline
\end{tabular}

Lobular and portal tract areas of liver sections were photographed under light microscopy and followed by appropriate magnification to estimate the number of IL-6 positive cells. Patterns of distribution of stained endothelial cells in hepatic lobules were divided into three groups: spotty type, or cells distributed in less than $25 \%$ of the lobule; focal type, or between $25 \%$ and $50 \%$; and diffuse type, or greater than $50 \%$ of the lobule. The numbers of IL- 6 positive infiltrating mononuclear cells, seen mainly at portal tracts, was graded on a + to +++ scale, corresponding to positivity in $1-5 \%, 6-10 \%$, and greater than $10 \%$ of total numbers of infiltrating mononuclear cells examined.

\section{Results}

The main cell elements staining positive for IL-6 in hepatic lobules were the sinusoidal endothelial cells. IL-6 positive endothelial cells were more numerous and diffusely distributed in lobules in acute viral hepatitis than in chronic viral hepatitis (table and fig 1). Expression of IL- 6 in endothelial cells was particularly increased in focal necrotic areas of hepatocytes and accompanied by IL- 6 positive Kupffer cells and infiltrating mononuclear cells.

In contrast, IL- 6 positive infiltrating mononuclear cells were more common in portal tracts than in lobules (fig 2). The number of mononuclear cells staining for IL-6 was increased in chronic active hepatitis compared with chronic persistent hepatitis, regardless of the aetiology of the disease (table). The staining appeared to be localised within the cytoplasm. Most of the fibroblasts were also IL -6 positive. Vascular walls were also stained, while hepatocytes and bile duct cells were not.

In patients with non-specific reactive hepatitis IL- 6 positive endothelial cells were found only occasionally in lobules (fig 3). In patients with liver cirrhosis positive staining of endothelial cells was enhanced and diffusely distributed.

\section{Discussion}

Most of the hepatic sinusoidal endothelial cells stained positively for IL-6 in patients with

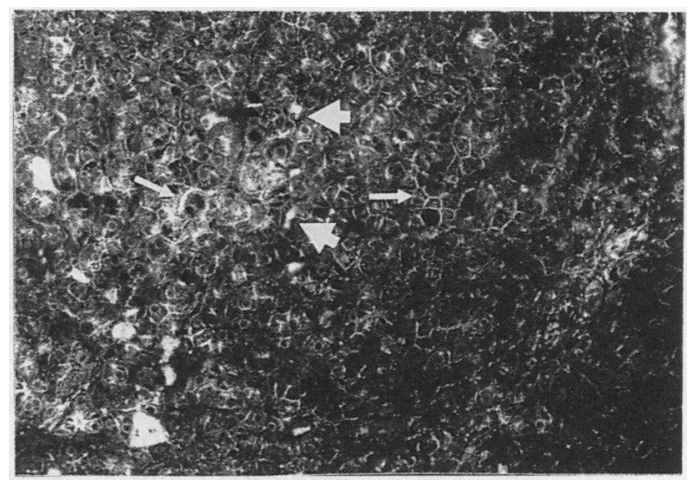

Figure 1 Enchanced expression of IL-6 in sinusoidal endothelial cells $(\longrightarrow$ ) and Kupffer cells $(-)$ around focal necrotic area of hepatocytes in a patient with acute non- $A$, non- $B$ hepatitis.

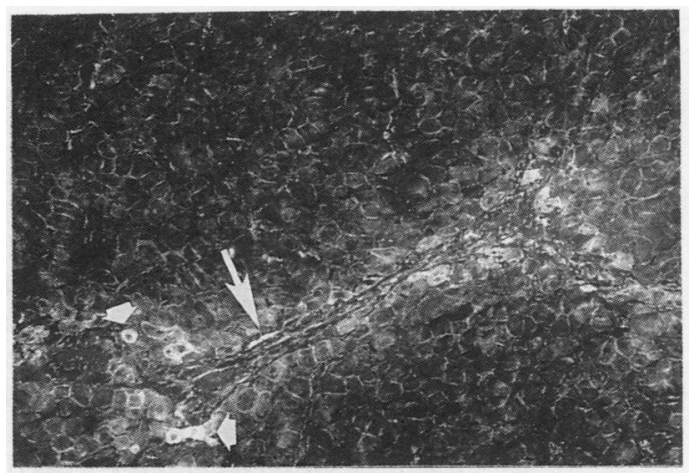

Figure 2 IL-6 stained infiltrating mononuclear cells (1gure) at a portal area in a patient with $\mathrm{HBeAg}$ positive chronic active hepatitis. Fibroblasts $(\longrightarrow$ ) were also stained for $I L-6$.

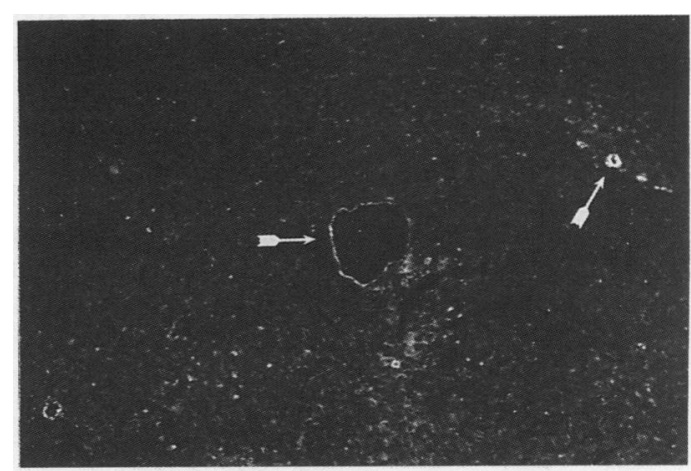

Figure 3 Most cells were negative for IL-6 staining except for vascular wall cells (-) in a patient with non-specific reactive hepatitis. 
acute viral hepatitis. IL-6 expression of endothelial cells was enhanced particularly in focal necrotic area of hepatocytes and Kupffer cells, the fixed tissue macrophages of the liver, were also positively stained, along with some IL-6 positive infiltrating mononuclear cells. These findings suggest that locally produced IL-6 may contribute to the acute inflammatory process of the disease.

In contrast, IL-6 staining infiltrating mononuclear cells was more noticeable in portal tracts than in lobules and their prevalence was greater in chronic active hepatitis than in chronic persistent hepatitis, indicating that local expression of IL-6 correlates with disease activity regardless of its aetiology. IL-6 is probably secreted by mononuclear cells in focal inflammatory areas that have spread into surrounding areas, thereby modulating the inflammatory and immune reaction in chronic liver disease. Although most of infiltrating mononuclear cells have been reported to be cytotoxic $T$ cells, ${ }^{16}$ the microscopic observation of FITC staining was insufficient to identify the cell type of mononuclear cells responsible.

Although hepatocytes showed negative staining for IL-6 in this study, IL-6 seemed to bind preferentially to periportal hepatocytes ${ }^{17}$ and only a small fraction of IL-6 was taken up by the specific receptors of hepatocytes. ${ }^{18}$ Previous studies have confirmed that acute phase protein in hepatocytes is regulated by a variety of cytokines including IL-6. ${ }^{1-4}{ }^{11}$ Lotz et al also showed that human hepatoma cells as well as primary hepatocytes produce IL-6 activity and express IL-6 proteins and mRNA. ${ }^{19}$ Furthermore, in thyroiditis epithelial cells were found to express IL- 6 using in situ hybridisation and immunohistochemical methods. ${ }^{89}$ Therefore, we cannot exclude the possibility that hepatocytes produce IL-6 in patients with acute and chronic liver disease. We may need to use more sensitive methods with molecular biology techniques.

In the steady state IL-6 is usually not produced by normal cells, but its expression is readily induced by viral infections. ${ }^{20}{ }^{21}$ In vitro exposure to human immunodeficiency virus (HIV) also induces the expression of IL-6 mRNA and the secretion of IL- 6 by monocytes or macrophages. ${ }^{22}$ It has also been noted that the most potent inducers of IL- 6 in the Kupffer cells of rats are viruses. ${ }^{23}$ Endothelial cells also can produce IL- 6 after stimulation by IL- 1 and TNF- $\alpha .{ }^{2425}$ IL- 6 shares many of its biological activities with IL-1 and TNF- $\alpha,{ }^{26}$ and thus the three cytokines probably act in concert, directing inflammatory and immunological reactions. For example, our previous study disclosed that TNF- $\alpha$ was produced by infiltrating mononuclear cells in focal inflammatory areas of the liver, suggesting that the numbers of TNF positive cells correlated with the degree of inflammatory activity of chronic liver disease. ${ }^{27}$

Finally, this study has shown that endothelial, Kupffer, and infiltrating mononuclear cells in liver tissue were activated to produce IL- 6 by hepatitis virus infection, contributing to the inflammatory and immune responses in acute and chronic hepatitis. Simultaneously,
IL-6 might provide the stimulatory signals for hepatocytes, resulting in their regeneration. ${ }^{28}$ This is similar to a process in renal mesangial cells for which IL-6 was an autocrine growth factor. ${ }^{29}$ In alcoholic liver cirrhosis, serum concentrations and production by leucocytes of IL-6 were increased..$^{30}$ Our study also showed that intrahepatic IL-6 expression was increased, suggesting that excess cytokines could lead to tissue damage and fibrosis. ${ }^{31}$

1 Hirano T, Yasukawa $\mathrm{K}$, Harada $\mathrm{H}$, et al. Complementary DNA for novel human interleukin (BSF-2) that induces B lymphocytes to produce immunoglobulin. Nature 1986;324:73-6.

2 Hirano $T$, Kishimoto $T$. Interleukin 6. In: Sporn MB, Roberts $\mathrm{AB}$, eds. Handbook of experimental pharmacology. Vol 95/I, Peptide growth factors and their receptors I. Heidelberg: Springer-Verlag, 1990:633-65.

3 Van Snick J. Interleukin-6: an overview. Ann Rev Immunol 1990;8:253-78.

4 Wolvekamp MCJ, Marquet RL. Interleukin-6: Historical background, genetics and biological significance. Immuno Lett 1988;24:1-10.

5 Hirano T, Matsuda T, Turner M, et al. Excessive production of interleukin-6/B-cell stimulatory factor-2 in rheumatoid arthritis. Eur J Immunol 1988;18:1797-801.

6 Houssiau FA, Devogelaer JP, Van Damme J, Nagant de Deuxchaisnes C, Van Snick J. Interleukin 6 in synovial fluid and serum of patients with rheumatoid arthritis and other inflammatory arthritides. Arthritis Rheum 1988;31:784-8.

7 Waage A, Kaufmann C, Espevik T, et al. Interleukin-6 in synovial fluid from patients with arthritis. Clin Immuno Immunopathol 1989;50:394-8.

8 Grubeck-Loebenstein B, Buchan G, Chantry D, et al. Analysis of intrathyroidal cytokine production in thyroid autoimmune disease: thyroid follicular cells produce interleukin-1 and interleukin-6. Clin Exp Immunol 1989;77:324-30.

9 Zheng RQH, Abney E, Chu CQ, et al. Detection of interleukin-6 and interleukin-1 production in huma thyroid epithelial cells by non-radioactive in situ hybridization and immunohistochemical methods. Clin Exp Immunol 1991;83:314-9.

10 Horii Y, Muraguchi A, Iwano M, et al. Involvement of IL-6 in mesangial proliferative glomerulonephritis. J Immuno 1989;143:3349-55.

11 Andus T, Bauer J, Gerok W. Effects of cytokines on the liver. Hepatology 1991;13:364-75.

12 Leevy CM, Popper H, Sherlock S. Disease of the liver and biliary tract. In: Standardization of nomenclature, diagnostic criteria and diagnostic methodology. London: Castle House Publications, 1979.

13 Okamoto H, Okada S, Sugiyama J, et al. Detection of hepatitis C virus RNA by a two-stage polymerase chain reaction with two pairs of primers deduced from the 5 noncoding region. Japan J Exp Med 1990;60:215-22.

14 Fukatsu A, Matsuo S, Tamai H, Sakamoto N, Matsuda T, Hirano T. Distribution of interleukin 6 in normal and diseased human kidney. Lab Invest 1991;65:61-6.

15 Matsuda T, Hirano T, Kishimoto T. Establishment of a IL6/BSF-2-dependent cell line and preparation of an antiIL-6/BSF-2 monoclonal antibodies. Eur $J$ Immunol 1988;18:951-6.

16 Papae GR, Rieber EP, Eisenburg J, et al. Involvement of the cytotoxic suppressor T-cell subset in liver tissue injury of patients with acute and chronic liver diseases. Gastroenterology 1983;85:657-62.

17 Bernuau D, Legres L, Lamri Y, Giuily N, Fey G, Feldmann G. Heterogeneous lobular distribution of hepatocyte expressing acute-phase genes during the acute inflammatory reaction. J Exp Med 1989;170:349-54

18 Sonne O, Davidsen O, Moler BK, Munck PC. Cellular targets and receptors for interleukin-6. I. In vivo and in vitro uptake of IL -6 in liver and hepatocytes. Eur $J$ Clin Invest 1990;20:366-70.

19 Lotz M, Zuraw BL, Carson DA, Jirik FR. Hepatocytes produce interleukin-6. Ann NY Acad Sci 1989;557: 509-11.

20 Sehgal PB, Helfgott DC, Santhaanam, et al. Regulation of the acute phase and immune responses in viral disease. Enhanced expression of the beta2-interferon/hepatocytestimulating factor/interleukin 6 gene in virus-infected stimulating factor/interleukin 6 gene in virus-in

21 Frei K, Malipiero UV, Leist TP, Zinkernagel RM, Schwab ME, Fontana A. On the cellular source and function of ME, Fontana A. On the cellular source and function of interleukin 6 production in the central nervous
viral disease. Eur J Immunol 1989;19:689-94.

22 Nakajima K, Martinez-Maza O, Hirano T, et al. Induction Nakajima K, Martinez-Maza O, Hirano T, et al. Induction
of IL-6 (B cell stimulatory factor-2/IFN- $\beta 2$ ) production by HIV. J Immunol 1989;142:531-6.

23 Busam KJ, Bauer TM, Bauer J, Gerok W, Decker K. Interleukin-6 release by rat liver macrophages. $J$ Hepato 1990;11:367-73. 
24 Jirik FR, Podor TJ, Hirano T, et al. Bacterial lipopolysaccharide and inflammatory mediators augment IL-6 secretion by human endothelial cells. J Immunol 1989;142:144-7.

25 Sironi M, Breviario F, Proserpio P, et al. IL-6 production in endothelial cells. J Immunol 1989;142:549-53.

26 Le J, Vileck J. Biology of disease. Tumor necrosis factor and interleukin-1: cytokines with multiple overlappin biological activities. Lab Invest 1987;56:234-9.

27 Yoshioka K, Kakumu S, Arao Y, et al. Immunohistochemical studies of intrahepatic tumor necrosis factor $\alpha$ in chronic liver disease. J Clin Pathol 1990;43:298-302.

28 Kuma S, Inaba M, Ogata $H$, et al. Effect of human recombinant interleukin- 6 on the proliferation of mouse hepatocytes in the primary culture. Immunobiol 1990;180:235-42.

29 Ruef C, Budde K, Lacy J, et al. Interleukin 6 is an autocrine growth factor for mesangial cells. Kidney Int 1990;38: 249-57.

30 Deviere J, Content J, Denys C, et al. High interleukin-6 serum levels and increased production by leucocytes in alcoholic liver cirrhosis. Correlation with IgA serum levels and lymphokines production. Clin Exp Immunol 1989; 77:221-5.

31 Khoruts A, Stahnke L, McClain CJ, Logan G, Allen JI. Circulating tumor necrosis factor, interleukin-1 interleukin-6 concentrations in chronic alcoholic patients. Hepatology 1991;13:267-76. 